\title{
INDEPENDENSI DAN URGENSI RESTRUKTURISASI SISTEM PERADILAN PIDANA INDONESIA BERDASARKAN ASPEK KEKUASAAN KEHAKIMAN
}

\author{
${ }^{1}$ Rico Yodi Tri Utama, ${ }^{2}$ Retno Saraswati \\ Program Magister Ilmu Hukum, Fakultas Hukum, Universitas Diponegoro, Semarang, Jawa Tengah. \\ Correspondent email : ricoutama56@gmail.com
}

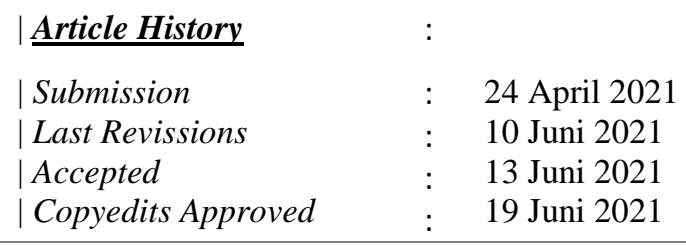

\begin{abstract}
Abstrack
Settlement of crimes by the criminal justice subsystem as a whole often does not run optimally. The position of the subsystems that are under the executive branch is sometimes used as a tool by the authorities to achieve their political goals regardless of the prevailing legal principles. This study aims to provide an overview of the position and function of criminal justice subsystems and focuses on finding the ideal system concept so that the implementation of an independent criminal justice system can be optimally realized by implementing a systems approach and restructuring the legal system. This study uses a normative juridical research method with a statute approach which is studied using a descriptive analysis. Based on the research results, the components of the criminal justice subsystem seem separate from one another, giving rise to sectoral egos and not yet showing the independence of each criminal justice subsystem. On that basis, to create an integrated, free and independent criminal justice system without any influence from power, it must provide a clear space for judicial independence (judicial power), thus placing the Supreme Court as the supervisor and controller of the entire criminal law enforcement process. The criminal justice subsystems must be under one door, not fragmented in other state institutions so that it is hoped that these subsystems can work optimally and be free from the influence of power.
\end{abstract}

Keywords: Criminal; Justice System; Independence; Reconstruction; Judicial Power. 


\section{A. PENDAHULUAN}

Sistem Peradilan Pidana merupakan sistem peradilan yang menganut prinsip Ketuhanan yang bertujuan menegakkan prinsip Keadilan bagi masyarakat sesuai dengan Pancasila. Peradilan yang adil (fair trail) akan menjadi suatu prinsip terbangunnya masyarakat dan sistem hukum yang adil. Perjuangan untuk menjadikan fair trail telah diterapkan semenjak disahkannya maha karya agung bangsa Indonesia Undang-Undang Nomor 8 Tahun 1981 Tentang Kitab Undang-Undang Hukum Acara Pidana yang mengubah sistem beracara pidana di Indonesia. Paradigma yang dibangun dalam KUHAP mengenai tersangka atau terdakwa dipandang sebagai subjek hukum tidak lagi sebagai objek hukum sehingga tersangka atau terdakwa mempunyai hak dan kewajiban berdasarkan hukum.

Sasaran akhir Sistem Peradilan Pidana yang menganut due process of law akan membentuk hukum yang adil, layak dan tidak memihak sesuai dengan prosedur-prosedur yang diatur. A. Hamzah menjelaskan bahwa peradilan yang jujur dan tidak memihak, hakim dalam menjalankan tugas dan tupoksinya selaku corong undang-undang tidak membedabedakan para pihak yang bersengketa. Hal ini terlihat dari irah-irah putusan hakim yang wajib mencantukan "Demi Keadilan Berdasarkan Ketuhanan Yang Maha Esa". Keadilan yang dicantumkan dalam irah-irah putusan hakim tersebut menandakan bahwa keadilan yang Seobyektif-objektifnya, dengan pemeriksaan dilakukan oleh 3 (tiga) orang hakim, jaksa penuntut umum dan penasehat hukum yang semuanya dilakukan dengan sidang terbuka untuk umum dan tetap sesuai dengan prosedur dan asas-asas hukum yang berlaku. Secara teori bahwa keadilan yang dianut sistem peradilan pidana tersebut memberikan keadilan yang berimbang terhadap para pihak yang bersengketa.

Rekontruksi sistem peradilan pidana dalam kekuasaan kehakiman sebagai langkah untuk mewujudkan sistem peradilan pidana yang merdeka dan bersih. Sebagaimana disampaikan oleh Barda Nawawi Arief bahwa "kekuasaan kehakiman adalah kekuasaan demi tegaknya hukum serta keadilan agar terwujudnya negara hukum itu". Selain itu kekuasaan kehakiman mampu dimaknai sebagai kekuasaan untuk menegakkan hukum dan tidak hanya sebagai kekuasaan mengadili saja. kekuasaan kehakiman dilihat dari perspektif lain yaitu sistem peradilan pidana merupakan kekuasaan dibidang hukum pidana yang meliputi keseluruhan wewenang dalam penegakkan hukum pidana antara lain kekuasaan penyidikan, penuntutan, mengadili serta pelaksanaan putusan.

Dalam sistem peradilan pidana, Barda Nawawi Arief pernah menjelaskan subsistem peradilan pidana yang diwujudkan melalui 4 (empat) subsistem diantaranya:

1. Kewenangan "Penyidikan" oleh Badan/ lembaga Penyidik

2. Kewenangan "Penuntutan" oleh badan/lembaga Penuntut Umum

3. Kewenangan "mengadili dan menjatuhkan putusan/pidana" oleh Badan Pengadilan

4. Kewenangan "pelaksanaan Putusan Pidana" oleh Aparat Pelaksanaan pidana/ Eksekusi 
Hakekat lembaga sistem peradilan pidana secara luas merupakan suatu lembaga yang dijadikan organ ( bentuk / wadah ), disisi lain functie merupakan isi sesuai dengan tujuan dari pembentukannya. Lembaga atau organ sistem peradian pidana adalah instrumen Eksekutif yang diselenggarakan bersamaan dengan lembaga pengadilan yaitu penopang kekuasaan yudikatif. Hal ini memperlihatkan tidak adanya sinkronisasi antara kedua dimensi (organ dan fungsi ). Sistem penegakan hukum yang berada di lembaga kekuasaan yang berbeda akan sering menimbulkan permasalahan yang bermuara seperti sistem peradilan pidana tidak berjalan secara optimal.

Mardjono Reksodipuro berpendapat komponen sistem peradilan pidana teridir dari beberapa subsistem yaitu "kepolisian", "kejaksaan", "pengadilan" dan "lembaga pemasyarakatan" yang diharapkan dapat bekerjasama membentuk suatu "Sistem Peradilan Pidana terpadu" atau "Intergrated Criminal Justice System". Jika subsistem peradilan pidana tidak terpadu maka diperkirakan terjadi tiga hal kerugian 1) Kesulitan untuk melakukan penilaian keberhasilan dan kegagalan dari masing-masing instansi, 2) kesukaran dalam memecahkan permasalahan masing masing instansi sebagai subsistem dari peradilan pidana, 3) Tanggungjawab masing-masing instansi sering terjadi ketidak jelasan, sehingga setiap instansi tidak memperhatikan efektifitas menyeluruh dalam sistem Peradilan pidana yang mengakibatkan adanya egosektoral.

Dalam sistem peradilan pidana yang tidak dibawah satu kelembagaan sangat tidak menguntungkan sebagai satu kesatuan manajemen peradilan. Hal ini dapat menyebaban terjadinya kurang independenya subsistem peradilan pidana serta gampang terintervensinya oleh faktor kekuasaan - kekuasaan lain, entah dari eksekutif maupun induk organisasi. Salah satu faktor utama dari adanya kekuasaan kehakiman yang independen serta merdeka adalah usaha dalam mencapai tujuan negara hukum yang berkeadilan. Dalam penegakannya, diperlukan adanya sinkronisasi yang menyeluruh. Tidak hanya diperlukan pembaharuan substansi hukum, tetapi juga pembaharuan struktur hukum, serta pembaharuan budaya hukumnya.

Dengan demikian, permasalahan yang mampu diambil dalam kajian ini adalah bagaimana fungsi, kedudukan, independensi dari sistem peradilan pidana dalam penyelenggaraan kekuasaan kehakiman serta faktor apakah yang mempengaruhi penyelenggaraan kekuasaan kehakiman yang mandiri serta independensi dan bagaimana restrukturisasi membangun keterpaduan Sistem Peradilan secara intergral agar bekerja secara optimal.

\section{B. METODE PENELITIAN}

Menyelesaikan suatu permasalahan hukum sejatinya harus disertai dengan metode penelitian yang bertujuan untuk melakukan suatu analisis dan konstruksi yang dilakukan secara metedologis sistematis dan konsisten. Dalam penelitian ini menggunakan metode penelitian yuridis normatif dengan pendekatan perundang-undangan (Statute Approach). 
Pendekatan statute approach disini memiliki arti pendekatan yang dititikberatkan terhadap legislasi dan regulasi hukum. Spesifikasi penelitian yang digunakan adalah deskriptif analistis sebagai cara untuk mengkaji permasalahan hukum yang dibahas. Penelitian ini menggunakan data primer yang terdiri dari bahan hukum primer berupa peraturan perundang-undangan yang berhubungan dengan Independensi dan Urgensi Rektrukturisasi Sistem Peradilan Pidana Indonesia Berdasarkan Aspek Kekuasaan Kehakiman disertai dengan bahan hukum sekunder yang terdiri dari buku, jurnal-jurnal, artikel atau sejenisnya yang terkait. Hingga penarikan kesimpulan dilakukan dengan menggunakan analistis data secara kualitatif guna mengungkap kebenaran baik formil atau materil.

\section{HASIL DAN PEMBAHASAN}

\section{Fungsi Dan Kedudukan Sub-sistem Sistem Peradilan Pidana dalam Penegakan} Hukum Pidana.

\section{a. Sub-sistem Penyidikan}

1) Penyidik Kepolisian Negara Republik Indonesia (POLRI)

Dalam sistem hukum Indonesia kepolisian sebagai ujung tombak sistem peradilan pidana. Kepolisian yang memiliki peran sentral dalam sistem peradilan pidana di Indonesia harus mengupayakan agar usaha preventif dan represif dalam penanggulangan tindak pidana dapat berjalan sebaik-baiknya. Sesuai dengan Pasal 13 Undang-Undang Nomor 2 Tahun 2002 tentang Kepolisian Republik Indonesia (UU Kepolisian), Bahwa Kepolisian mempunyai tugas pokok untuk "pemeliharaan dan ketertiban masyarakat; menegakkan hukum dan memberikan perlindungan, pengayoman dan pelayanan kepada masyarakat". Dalam menjalankan tugasnya Kepolisian harus lebih mandiri, profesional serta independen. Sesuai Pasal 1 angka (2) Undang-Undang Nomor 8 Tahun 1981 Tentang Kitab Undang-Undang Hukum Acara Pidana, "Penyidikan adalah serangkaian tindakan penyidik dalam hal dan menurut cara yang diatur dalam undang-undang ini untuk mencari serta mengumpulkan bukti yang dengan bukti itu membuat terang tentang tindak pidana yang terjadi dan guna menemukan tersangkanya". Dalam Pasal 1 angka (1), proses penyidikan dilakukan oleh "pejabat kepolisian" atau "pejabat pegawai negeri sipil" yang telah ditentukan dalam peraturan perundang-undangan.

Kewenangan Kepolisian dalam proses penyidikan dilakukan oleh satuan reserse yang memiliki kewenangan melaksanakan penyelidikan, penyidikan dan koordinasi dan pengawasan terhadap Penyidik Pegawai Negeri Sipil (PPNS). Dalam proses penyidikan institusi kepolisian wajib independen dan merdeka dalam mengungkap pelaku tindak pidana, bagaimana dan mengapa dia melakukan tindak pidana tersebut. namun jika mengamati hukum positif di Indonesia yang 
mengatur mengenai kepolisian, dapat disimpulkan bahwa kedudukan kepolisian itu berada langsung dibawah Presiden dimana posisi lembaga kepolisian berada lebih rendah dari posisi Presiden dapat diartikan bahwa lembaga kepolisian tunduk kepada Presiden selaku pemegang kekuasaan eksekutif. Jika memperhatikan tugas dan kewenangan yang dimiliki kepolisian secara otomatis wajib bertanggungjawab kepada presiden selaku pemegang kekuasaan. Kedudukan Kepolisian dalam proses penegakan hukum baik penyelidikan dan penyidikan seharusnya tidak berada dibawah pengaruh presiden karena sangat dimungkinkan penegakan hukum akan cenderung dipolitisasi dan disalahgunakan.

2) Penyidik Pegawai Negeri Sipil

Penyidik Pegawai Negeri Sipil (PPNS) dalam hukum Indonesia diatur dalam Pasal 6 ayat (1) huruf b KUHAP yang berbunyi penyidik adalah "pejabat pegawai negeri sipil tertentu yang diberi wewenang khusus oleh undang-undang". Dapat diartikan bahwa PPNS sebagai penyidik yang ditujukan untuk melakukan penyidikan hanya terhadap kasus tertentu berbeda dengan kepolisian. Dalam menjalankan tugas dan fungsinya PPNS diberikan kewenangan untuk melakukan upaya paksa maupun wewenang lainnya guna melancarkan proses penyidikan. Beberapa Penyidik pegawai negeri sipil yang diembankan untuk melakukan penyidikan seperti;

1. PPNS tindak pidana Merek diatur dalam Undang-Undang No. 20 Tahun 20016 tentang Merek

2. PPNS tindak pidana perikanan diatur dalam Undang-Undang No. 31 Tahun 2004 tentang Perikanan sebagaimana telah diubah dengan UndangUndang No. 45 Tahun 2009 tentang Perubahan Atas Undang-Undang No. 31 Tahun 2004 tentang Perikanan

3. PPNS tindak pidana perlindungan dan pengelolaan lingkungan hidup diatur dalam Undang-Undang No. 32 Tahun 2009 tentang Perlindungan Dan Pengelolaan Lingkungan Hidup

4. PPNS tindak pidana perusakan hutan diatur dalam Undang-Undang No. 18 Tahun 2013 tentang Pencegahan dan Pemberantasan Perusakan Hutan

5. PPNS tindak pidana di bidang Kepabeanan diatur dalam Undang-Undang No. 10 Tahun 1995 tentang Kepabeanan yang telah mengalami perubahan menjadi Undang-Undang Nomor 17 Tahun 2006 Tentang Perubahan Atas Undang-Undang Nomor 10 Tahun 1995 Tentang Kepabeaan.

Peraturan perundang undang-undangan hingga saat ini telah memberikan kewenangan penyidikan kurang lebih 52 (lima puluh dua) jenis PPNS yang terletak diberbagai lembaga negara. Banyaknya PPNS tersebut akan menimbulkan terjadinya permasalahan dalam hal melakukan upaya paksa, pemberitahuan 
dimulai penyidikan (SPDP), fungsi koordinasi dan penyampaian berkas perkara. Sehingga sangat dimungkinkan terjadi disharmonisasi antar PPNS yang satu dengan yang lainnya.

3) Penyidik Kejaksaan

Kejaksaan adalah suatu institusi dalam sistem peradilan pidana yang memiliki kewenangan untuk melakukan penuntutan dan membuat dokumen seperti dakwaan dan surat tuntutan, sehingga dapat dikatakan bahwa jaksalah sebagai tokoh utama dalam penyelenggara peradilan pidana. Kejaksaan yang menyandang asas dominus litis memiliki fungsi yang dominan dalam proses penuntutan. Dalam proses peradilan pidana, kejaksaan tidak hanya memiliki kewenangan untuk melakukan penuntutan atau melaksanakan putusan hakim, akan tetapi kejaksaan juga diberikan kewenangan untuk melakukan penyidikan. Hal ini dapat terlihat dalam Pasal 30 ayat (1) huruf d UU Nomor 16 Tahun 2004 Tentang Kejaksaan yang berbunyi "Kejaksaan mempunyai tugas dan kewenangan untuk melakukan penyidikan terhadap tindak pidana tertentu berdasarkan undangundang".

Proses penyidikan oleh kejaksaan dapat terlihat dalam penanganan kasus tindak pidana korupsi. Kewenangan jaksa untuk melakukan penyidikan sekaligus penuntutan akan menghapuskan mata rantai pra penuntutan sehingga tidak akan terjadi bolak-balik berkas, sehingga proses penyelesaian perkara diharapkan dapat diselesaikan secara efektif dan efesien.

4) Penyidik Komisi Pemberantasan Korupsi

Komisi Pemberantasan Korupsi merupakan suatu lembaga negara yang ditugaskan untuk mencegah dan memberantasan tindak pidana korupsi yang bersifat independen dan bebas dari kekuasaan manapun. Sesuai dengan Pasal 6 huruf e UU Nomor 19 Tahun 2019 Tentang Perubahan Kedua Atas UndangUndang Nomor 30 Tahun 2002 Tentang Komisi Pemberantasan Tindak Pidana Korupsi, "Komisi Pemberantasan Korupsi bertugas melakukan penyelidikan, penyidikan dan penuntutan terhadap Tindak Pidana Korupsi”. Penyidik KPK diangkat dan diberhentikan oleh Komisi Pemberantasan Korupsi yang menjalankan fungsi penyidikan tindak pidana korupsi. Dalam menjalankan tugas dan kewenangan, Sesuai Pasal 10 A ayat (5) KPK dalam hal Penyidikan berwenang untuk mengambil alih penyidikan dan/atau penuntutan terhadap perlaku tindak pidana korupsi yang sedang dilakukan oleh kepolisian atau kejaksaan. Hal ini memberikan arti bahwa KPK merupakan suatu lembaga super power dalam pemberantasan tindak pidana korupsi.

Kewenangan yang dimiliki KPK bisa digolongkan sangat kompleks, namun dalam proses perekrutan penyidik KPK yang dibatasi akan menimbulkan 
stigma negative dalam penegakan hukum pidana yang harus independen. Hal ini terlihat dalam undang-undang KPK yang menjelaskan penyidik KPK dapat berasal dari Kepolisian, Kejaksaan, PPNS dan penyelidik KPK, padahal sesuai dengan Putusan Mahkamah Konstitusi Tahun 2006 menjelaskan bahwa KPK dapat melakukan perekrutan dari instansi kepolisian atau kejaksaan. Akibat perubahan yang ada dalam undang-undang KPK, dapat dikatakan bahwa KPK yang pada prinsipnya harus bersifat independen, akan tetapi penyidik KPK yang hanya dibatasi dari instansi tertentu yang secara hukum, penyidik yang berasal dari instansi tertentu akan bertanggungjawab terhadap instansi asalnya. Selain itu, putusan MK tersebut bertujuan untuk mencegah loyalitas ganda para penyidik KPK, namun dalam pelaksanaanya masih tetap memberikan ruang kepada kejaksaan dan kepolisian sehingga dalam proses rekrutmen penyidik KPK dikhawatirkan terdapat interpensi dari lembaga negara lain.

5) Penyidik Angkatan Laut

Menjaga dan mempertahankan kedaulatan bangsa di perairan Indonesia dilakukan oleh TNI Angkatan Laut. Kewenangan yang dimiliki oleh TNI Angkatan Laut dalam menegakkan hukum sesuai dengan Pasal 9 huruf b UU Nomor 34 Tahun 2004 diantaranya melakukan pengejaran, penangkapan, penyidikan dan penyelidikan yang selanjutnya berkas hasil penyidikan Angkatan Laut akan diberikan kepada Jaksa untuk melakukan penuntutan disidang pengadilan. Dalam menjalankan tugas dan tupoksi dalam hal penyidikan oleh Angkatan Laut tidak dapat berjalan dengan optimal karena beberapa keterbatasan yaitu keterbatasan personil dan keterbatasan sarana prasarana.

Kewenangan yang diberikan kepada Penyidik Angkatan Laut untuk melakukan penyidikan bertujuan untuk melakukan penegakan hukum diwilayah perairan Indonesia, menjaga dan melindungi sumberdaya alam baik hayati dan hewani serta menjaga kekayaan alam yang berada dilaut nasional serta mampu memberikan keamanan dan ketertiban di laut dan mendukung pembangunan bangsa dalam sector perairan nusantara.

\section{b. Sub-sistem Penuntutan}

Penuntutan secara yuridis adalah tindakan oleh penuntut umum untuk melimpahkan perkara pidana ke Pengadilan Negeri sesuai yang tercantum dalam undang-undang (Pasal 1 butir 7 KUHAP). Dalam sistem peradilan pidana di Indonesia undang-undang hanya memberikan kepada 2 (dua) lembaga negara untuk melakukan penuntutan yaitu tindak pidana umum beserta tidak pidana khusus lainnya dilakukan oleh jaksa sedangkan untuk tindak pidana korupsi dilakukan oleh KPK maupun Kejaksaan. 
1) Penuntut Umum Lembaga Kejaksaan

Sesuai dengan Pasal 2 UU Nomor 16 Tahun 2004 tentang Kejaksaan RI, bahwa kejaksaan sebagai lembaga pemerintahan mengemban dan melaksanaan kekuasaan negara dibidang penuntutan secara merdeka. Dalam sistem hukum Indonesia kejaksaan merupakan lembaga negara yang berada dibawah lembaga eksekutif, namun jika melihat tugas dan tupoksinya bahwa kejaksaan pada dasarnya merupakan lembaga negara yang ditugaskan untuk menegakkan keadilan sehingga sangat jelas bahwa kekuasaan kejaksaan berada dalam bidang yudikatif. Disinilah terjadi keambivalensian kedudukan kejaksaan sebagai penegak hukum. secara yuridis sesuai dengan Pasal 2 ayat (3) UU No. 16 Tahun 2004 Tentang Kejaksaan, bahwa kekuasaan kehakiman dalam menjalakan tugasnya harus dilakukan secara merdeka, namun kedudukan kejaksaan disatu sisi harus menegakkan hukum sebagai tugas pokok kejaksaan dan sebagai lembaga yang berada dilembaga eksekutif kejaksaan harus tunduk pada penguasa.

Kedudukan kejaksaan yang masih berada dibawah Presiden tidak ada jaminan kejaksaan akan menjalankan kewenangannya secara independen, padahal sangat jelas bahwa kejaksaan adalah salah satu elemen terpenting dalam penegakan hukum. Atas dasar itu menurut penulis independensi yang terbebas dari conflict of interest kejaksaan sangat sulit untuk dihindarkan. Meskipun dalam menjalankan tugas penyidikan oleh Kejaksaan harus bebas dan merdeka.

2) Lembaga Penuntut Umum KPK

Penuntutan terhadap tindak pidana korupsi mampu dilakukan oleh penuntut umum KPK. Hal ini dapat dilihat di dalam rumusan Pasal 6 huruf e UU No. 19 Tahun 2019 tentang Komisi Pemberantasan Tindak Pidana Korupsi, yaitu KPK mempunyai tugas melakukan tindakan penyelidikan, penyidikan, dan penuntutan terhadap tindak pidana korupsi. Sesuai dengan Pasal 3 UU KPK bahwa KPK merupakan lembaga negara yang berada dalam kekuasaan eksekutif. Padahal dasar berdirinya KPK harus bersifat Independen dan tidak ditempatkan dalam lembaga manapun sehingga menimbulkan kontraporduktif. Keberadaan KPK dalam lingkaran kekuasaan eksekutif akan terjebak terjadinya konflik kepentingan, hal ini dapat dilihat dalam proses keorganisasian yang mana KPK tetap tergantung kepada kekuasaan eksekutif dan berhubungan khusus dengan kekuasaan yudikatif dalam hal penuntutan dan penyidikan serta pelaksanaan sidang.

Personil Penuntut Umum Kejaksaan untuk sementara diperbantukan kepada KPK,dimana menjadi pegawai dibawah komando KPK ini merupakan bentuk adanya kurang mendukungnya sumber daya manusia darin KPK. Ketika sudah tidak diperlukannya tenaga bantuan dapat dialihkan kembali kepada instasi 
terkait (mengingat KPK bersifat Ad-Hoc), atau sewaktu-waktu bisa ditarik oleh instansinya apabila instansi asal membutuhkan. Kurang independennya serta kinerja yang kurang maksimal inilah yang memicu adanya kondisi seperti ini.

3) Sub-sistem Peradilan

Kekuasaan kehakiman diatur dalam Pasal 24 ayat (2) UUD 1945 jo. UU No. 48 tahun 2009 dalam Pasal 25, pada intinya menjelaskan Mahkamah Agung terdiri dari beberapa lingkup peradilan yaitu Peradilan Umum, Peradilan Agama, peradilan PTUN dan Peradilan Militer. Kewenangan masing-masing lembaga peradilan tersebut telah diatur dalam undang-undang. jika mengacu terhadap Pasal 24 ayat (2) UUD NRI 1945, Mahkamah Agung merupakan puncak dari peradilan. Selain itu dalam Pasal 20 ayat (1) UU No. 48 Tahun 2009 menjelaskan bahwa Mahkamah Agung adalah pengadilan negara tertinggi.

Mahkamah Agung sebagai puncak peradilan memberikan arti bahwa sejatinya penyelenggaraan sistem peradilan pidana harus berpuncak MA. Sehingga struktur organisasi, administrasi, finansial dan kepegawaian harus berada dibahwa kewenangan Mahkamah Agung. Atas dasar itu sistem satu atap dalam sistem peradilan pidana ditujukan untuk spirit independensi peradilan, namun pada faktanya subsistem peradilan pidana mementingkan sektoral semeta.

\section{c. Sub sistem Pelaksana Pidana}

Instansi teknis Direktorat Jenderal Pemasyarakatan atau lembaga pemasyarakatan diatur dalam UU No. 12 Tahun 1995 tentang Pemasyarakatan, yang mana merupakan bagian dari institusi Pemerintah (eksekutif) yang menjalankan rangkaian fungsi penegakan hukum, sebagai pelaksanaan pidana. Dalam pelaksanaan pidana diidentikan dengan pemberian sanksi pidana seperti penjara dan denda kepada pelaku tindak pidana untuk mencapai tujuan pidana yang berimbang. Pidana penjara yang dilaksanakan berdasarkan sistem pemasyarakatan merupakan bagian dari tujuan pemidanaan. Penetapan hukum berkaitan dengan kebijakan "pemidanaan" merupakan kewenangan dari Lembaga Pemasyarakatan. Selain itu, Lembaga Pemasyarakatan juga memiliki wewenang untuk "mengurangi" masa pidana yang ditetapkan Hakim. Hal tersebut dapat diartikan bahwa Lembaga Pemasyarakatan dapat "mengubah" putusan Hakim yang telah berkekuatan hukum tetap. Adapun kebijakan "perubahan" tersebut dapat dilaksanakan dengan instrumen pemberian "remisi" maupun "pelepasan bersyarat".

Dalam pelaksanaanya, lembaga pemasyarakatan yang berada dibawah Presiden juga harus bertanggungjawab terhadap Presiden selaku atasan. Hal ini jelas bahwa akan terdapat interpensi Presiden yang berujung terhadap pengaruh yang besar dari kepala negara, sehingga keputusan yang dikeluarkan oleh Hakim selaku 
corong undang-undang dengan sendirinya dapat membatasi pidana yang dijatuhkan terhadap terpidana.

\section{Faktor Penyebab Kekuasaan Kehakiman Tidak Merdeka dalam Penegakan Hukum Pidana}

Adapun beberapa faktor yang menjadikan kekuasaan kehakiman tidak independen dalam hal penegakan hukum pidana dikaji dari aspek kelembagaan.

a) Penyidik Kepolisian.

Garis komando yang masih sangat kuat dalam badan kepolisian berimplikasi pada Penyidik dalam hal melakukan kewenangannya yang bergantung dengan komando, menyebabkan penyidik tidak bertindak dalam kapasitas personal, tidak professional dan mandiri. Penyidik kerap tidak memiliki kedudukan yang terhormat dalam hal harga dirinya di mata tersangka, hal tersebut disebabkan karena perasaan tersangka yang merasa ada kedekatan dan dapat "menguasai" atasan.

Intervensi yang bersifat vertikal datang dari atasan yang memiliki kepentingan secara pribadi terhadap kasus yang sedang dalam tahap penyidikan oleh polisi reserse sebagai bawahannya. Wujud intervensi tersebut berupa komunikasi "minta dibantu" atau "minta ditunda". Secara administrasi, terkait dengan izin pemeriksaan tersangka yang memiliki kedudukan sebagai pejabat, kerap terhambat oleh izin yang bahkan tidak diberikan oleh tingkatan birokorasi administrasi (pengantar izin pemeriksaan), disebabkan karena faktor kepentingan pejabat atasan langsung yang tidak menginginkan kasus untuk ditindak lanjut.

Adapun penyebab lainnya yang menjadikan penyidik tidak independen ialah posisi pejabat structural resere (Kepala Unit, Satuan, Kepala Direktorat bahkan Kepala Badan) kerap terjadi bukan berasal dari pejabat yang berkarier dari serse, misalnya bisa dari Satuan Lalu Lintas. Masih minimnya pengetahuan baik di bidang identifikasi maupun manajemen dai segi sumber daya manusia polisi penyidik, menyebabkan sulitnya memperoleh penyidik yang professional. Pemeriksaan dalam tahap penyidikan terhadap semua jenis kejahatan masih dilakukan oleh reserse umum dan belum dilakukan oleh penyidik yang memiliki keahlian khusus terkait dengan jenis kejahatan yang terjadi. Dalam rangka meningkatkan sumber daya polisi penyidik peningkatan ilmu pengetahuan dan pendidikan berperan penting dalam rangka kemandiriannya.

b) Penyidik Pegawai Negeri Sipil (PPNS)

Dalam prakteknya yang ditemui dilapangan, PPNS kerap tidak independen, bahkan seolah-olah kedudukannya tersubordinasi dan ditempatkan sebagai pembantu Penyidik Kepolisian. PPNS yang berkedudukan dibawah pengawasan serta koordinasi penyidik Polri akan menimbulkan dampak yang menjadikan PPNS 
inferior, tidak ada kepercayaan diri dalam melakukan sebagaimana yang menjadi tugas dan wewenangnya, dan pada akhirnya mengkerdilkan mental, eksistensi, peran, dan kemampuan PPNS. Peran PPNS yang belum melaksanakan kewenangannya, untuk memberdayakan sumber daya manusianya dan makin terperangkap oleh sistem yang secara sistematis dapat melemahkan mereka

PPNS berkedudukan dalam bidang penyidikan (penegakan hukum) sebagai pembantu fungsi kepolisian. Hal ini sanga bertentangan dengan Pasal 1 angka (1) KUHAP yang secara tegas memberikan arti bahwa PPNS dan Kepolisian memiliki kedudukan yang sama dalam pelaksanaan penyidikan. Namun dalam Pasal 7 ayat (2) KUHAP PPNS dalam menjalankan tugasnya berada di bawah koordinasi dan pengawasan Penyidik Polri. Namun undang-undang juga memberikan kesempatan kepada PPNS untuk melakukan penyidikan dan menyerahkan berkas secara langsung kepada Jaksa Penuntut Umum.

Beberapa perundang-undangan menyatakan bahwa PPNS dapat menyerahkan secara langsung kepada Jaksa Penuntut Umum tanpa harus melalui Penyidik Polri. Dalam hal ini dapat ditarik benang merah bahwa kapasitas PPNS tidak sebagai pembantu Penyidik Polri, terlebih lagi sebagai "assesoris" atau "pelengkap" dalam fungsi penyidikan. Kemudian, dapat dikatakan bahwa penyalahgunaan fungsi PPNS sering terjadi, sehingga Polri dalam hal ini sanggup untuk mengambil alih kewenangan PPNS. Tindakan Kepolisian yang melakukan proses hukum terhadap PPNS yang melakukan tugasnya dalam hal penyidikan dinilai tidak positif karena berujung pada kasusnya yang tidak berlanjut. PPNS sebagai pegawai negeri sekaligus memiliki tugas tambahan dalam hal penyidikan secara internal keorganisasian PPNS sangat tidak independen. Dalam prakteknya, kinerja PPNS sering terhambat oleh ijin pimpinan dan oleh karena pendidikan yang ditempuh hanya beberapa bulan, maka dinilai tidak profesional dan tidak terhimpun dalam suatu badan.

c) Penyidik Kejaksaan

Kedudukan kejaksaan yang merupakan elemen dari sistem peradilan pidana dituntut untuk tetap menjaga independensinya dari adanya intervensi dari pihak manapun termasuk pihak eksekutif. Akan tetapi, hal tersebut secara konkret terlihat sulit bagi kejaksaan untuk bisa mandiri dari intervensi pihak eksekutif karena secara struktural, penempatan kejaksaan berada dibawah kekuasaan eksekutif. Kewenangan Presiden yang dapat mengangkat dan memberhentikan Jaksa Agung sebagaimana ditegaskan dalam UU No. 16 Tahun 2004 tentang Kejaksaan RI membuat posisi Jaksa Agung tidaklah independen. Berkaitan dengan periode masa jabatan Jaksa Agung, tidak ada penjelasan secara rinci. Kondisi yang demikian akan berpotensi hilangnya independensi kekuasaan penuntutan. Presiden kapanpun dapat 
memberhentikan Jaksa Agung sesuai keinginan Presiden, sehingga dalam hal melaksanakan tugas untuk menegakan hukum harus waspada, jangan sampai menyinggung kepentingan politik Presiden yang pada akhirnya membuat ia menjadi tidak independen.

Kedudukan yang tidak mandiri tersebut berakibat pada tidak independennya fungsi yang dilaksanakan karena sebagai pejabat pemerintah dituntut untuk memiliki loyalitas yang tinggi dalam melaksanakan fungsi-fungsi pemerintahan, walaupun terdapat jaminan kemerdekaan dalam melaksanakan fungsi penuntutan sebagaimana tertuang dalam Pasal 2 ayat (2) UU No. 16 Tahun 2004. Dalam kedudukan dan fungsi Kejaksaan, terdapat keadaan yang bersifat kontradiktif dan dilematis. Dalam indikatornya, terciptanya independensi sangat dipengaruhi oleh proses pemilihan serta pengangkatan kekuasaan Lembaga Yudisial dan hal tersebut merupakan indikator yang penting. Apabila dikaji lebih lanjut, proses pengangkatan Jaksa Agung yang hanya melibatkan Presiden, secara actual dapat mengurangi makna penting Jaksa sebagai pihak yang mewakili kepentingan umum dan penegakan hukum. Oleh karena itu, berdasarkan Pasal 19 ayat (2) jo. Pasal 22 Undang-Undang Nomor 16 Tahun 2004 dapat ditarik kesimpulan bahwa Jaksa Agung tidak independen.

d) Penyidik Komisi Pemberantasan Korupsi (KPK)

Kedudukan KPK sebagai lembaga negara dalam rumpun kekuasaan eksekutif sebagaimana diatur dalam Pasal 1 ayat (3), Pasal 3 UU No. 19 Tahun 2019 tentang KPK. Konsekuensinya, KPK bernuansa eksekutif. Hal ini dikarenakan proses kepagawaian, status penyidikan serta mutasi tunduk terhadap regulasi aparat sipil negara yang bercorak eksekutif. Meskipun dalam Pasal 3 UU KPK menjelaskan bahwa dalam proses penyidikan harus dilakukan secara independen namun kenyataanya sangat sulit, apabila KPK memiliki hubungan erat dengan Presiden secara vertical maka independensi KPK akan berubah menjadi Dependen.

Konsep lembaga negara independen tidak mengenal kelembagaan pengawas, namun yang dijadikan fokus adalah membangun sistem pengawasan. Apabila lembaga pemberantasan korupsi berada dibawah Presiden dan bertanggungjawab kepada Presiden maka sampai kapanpun pemberantasan tindak pidana korupsi tidak akan berjalan dengan efektif dan optimal. Seperti Badan Pengawas Kegiatan Aparatur Negara di bawah Soekarno dan Operasi Tertib di bawah Soeharto. Susan Baer menyatakan bahwa kehadiran lembaga independen muncul sebagai pemicu atas cara kerja lembaga konvensional yang tidak lagi optimal. Hal senada juga disampaian oleh Ackerman, menjelaskan lembaga independen merupakan gejala auto kritik terhadap pemisahan kekuasaan secara konvensional antara legislatif, eksekutif dan legislatif. 
Pasal 45 jo. Pasal 45 A menyatakan bahwa Penyidik KPK adalah penyidik yang berasal dari Kepolisian, Kejaksaan, instansi pemerintah lainnya, dan/atau internal KPK. Dalam perekrutan anggota penyidik KPK cenderung melibatkan kepolisian dan kejaksaan sehingga akan menimbulkan hilangnya independensi KPK dalam pengelolaan sumber daya manusia. Meskipun KPK memberikan syarat untu membuka peluang untuk instansi lainya namun sesuai pasa selanjutnya harus mempunyai kersama dengan kepolisian dan/atau kejaksan. Oleh karena itu, apabila masih adanya penyidik yang berasal dari Polri atau Kejaksaan, maka KPK tidak akan bisa bekerja secara independen atau sesuai pada jalurnya. Artinya di dalam penyidik independen ini diarahkan bebas oleh lembaga apapun.

e) Penyidik Tentara Nasional Angkatan Laut (TNI-AL)

Penegakan hukum yang dilakukan Oleh TNI AL terhadap terjadinya tindak pidana diperairan Indonesia merupakan suatu langkah untuk menjaga keamanan bangsa. Fungsi penyidikan yang diemban oleh Penyidik TNI AL, jika ditelusuri lebih luas bahwa penyidik yang berasal dari TNI AL merupakan anggota yang tunduk terhadap disiplin militer baik atasan maupun satuannya. Sehingga apabila TNI AL mempunyai kewenangan untuk melakukan penyidikan sangat dikawatirkan timbulnya kerawanan terjadinya pelanggaran Hak Asasi Manusia. Namun jika ditinjau dari segi kelembagaan maka TNI AL wajib mementingkan garis komando sehingga sangat besar timbulnya intervensi dari atas TNI AL dalam penegakan hukum di perairan Indonesia

\section{Restrukturisasi Sistem Peradilan Pidana Menuju Kekuasaan Kehakiman yang Merdeka Secara Integral}

a. Restrukturisasi Substansi Hukum

Pada dasarnya legal substance dalam bidang peradilan dan penegakan hukum pidana mencakup substansi hukum materil, hukum formil dan substansi hukum pelaksanaan/ eksekusi. Restrukturisasi substansi hukum yang dimkasud berkaitan dengan substansi hukum yang mengatur fungsi, kedudukan dan wewenang lembaga penegakan hukum pidana. Berbagai peraturan perundang-undangan yang mengatur sub-sistem masih belum memberi ruang dan atmosfir yang kondusif bagi independensi dan kemandirian kekuasaan kehakiman. Adanya aturan yang bersifat overlapping, keadaan ini muncul sehubungan beberapa aturan memberikan pengaturan kewenangan yang sama terhadap beberapa lembaga penegak hukum.

Banyak peraturan yang bersifat parsial dan belum integral dalam keseluruhan kekuasaan kehakiman, aturan yang tidak selaras, tidak harmonis dan inkonsistensi antara satu dengan lainnya. Selain itu, sesuai dengan telaah subtantif eksistensi dan relasi lembaga penegakan hukum dalam sistem peradilan pidana yang tidak harmonis menimbulkan ketidakpastian hukum dan tidak sesuai dengan fungsi dan tupoksi 
lembaga tersebut, bahkan bertentangan dengan ide reformulasi pada sistem peradilan pidana yang mengendepankan nilai nilai demokrasi sehingga perlu dilakukan penataan ulang maka sistem peradilan pidana terpadu harus dibawah kekuasaan kehakiman yang berdiri sendiri, bebas dan tidak terikat.

Jadi yang harus dilakukan ialah bagaimana peraturan perundang-undangan yang mengatur kekuasaan kehakiman memberikan ruang dan atmosfir yang tegas bagi independensi kekuasaan kehakiman dari pengaruh kekuasaan eksekutif maupun kekuasaan legislative misalnya dalam proses rekruitmennya dilakukan tanpa perlu melibatkan peran pemerintah maupun DPR, serta mengharmonisasikan antara peraturan yang satu dengan yang lainnya sehingga tidak ada tumpang tindih kewenangan antar sub-sistem.

b. Restrukturisasi Struktur Hukum

Dalam penegakan hukum pidana untuk mewujudkan integrated criminal justice system maka diperlukan sinkronisasi secara menyeluruh sub-sistem dalam sistem peradilan pidana yang ditata secara integral dalam tatanan baru. Kekuasaan kehakiman merupakan kekuasaan yang diberikan kewenangan untuk mengadili. Pengertian itu dikatakan dalam arti sempit. Barda Nawawi Arief menjalaskan bahwa kekuasaan kehakiman yang diselenggarakan bukan sekedar kekuasaan mengadili tetapi juga kekuasaan penegakan hukum dalam arti "luas".

Rekonstruksi proses peradilan pidana sangat perlu dilakukan guna menciptakan kekuasaan kehakiman yang merdeka, berkualitas dan memiliki integritas yang bagus. Penataan kembali kekuasaan kehakiman dalam rangka menjalankan kekuasaan penegakan hukum, yang memberikan kedudukan Mahkamah Agung sebagai otoritas tunggal dalam penyelenggaraan kekuasan kehakiman yang merdeka dan mandiri, mampu mengintegrasikan keseluruhan lembaga penegak hukum dalam menjalan sistem peradilan pidana.

Menempatkan Mahkamah Agung menjadi pengawas dan pengendali puncak/tertinggi dari keseluruhan proses penegakan hukum pidana (tahap penyidikan, penuntutan, peradilan, pelaksanaan pidana). Adanya pengendali puncak/tertinggi ini, merupakan konsekuensi logis dari manajemen sistem peradilan pidana yang terpadu. Tanpa adanya pengendali puncak, dikhawatirkan bekerjanya sistem peradilan pidana bersifat fragmentaris atau instansi sentries. Oleh karena itu, desain sistem peradilan yang berpuncak dalam satu atap sangat tepat diberlakukan Dengan demikian Komponen-komponen subsistem peradilan pidana tidak bisa dipandang secara parsial atau terpisah akan tetapi keseluruhan subsistem tersebut harus saling bekerja sama dan saling mendukung dalam kesatuan dan keterpaduan untuk mencapai tujuan sistem peradilan pidana. 
c. Restrukturisasi Budaya Hukum

Budaya hukum pelaksanaan penegakan tindak pidana saat ini muncul arogansi kelembagaan yang sifatnya inkonsistensi dan kontradiksi dalam penegakan hukum. Dewasa ini penegakan hukum cenderung mengutamakan kepentingan kekuasaan dibandingkan kepentingan masyarakat. Ego sektoral yang semakin lama semakin menjadi-jadi diantara subsistem peradilan pidana. Fenomena ini sudah terjadi sejak lama sehingga kepercayaan masyarakat terhadap penegakan hukum tergolong rendah. Ego sektoral yang semakin meningkat dikawatirkan akan menimbulkan moral para penegak hukum yang rendah.

Dalam realita yang terjadi dimasyarakat terdapat budaya amplop (mafia peradilan) dalam upaya penegakan hukum pidana. hal ini menandakan bahwa budaya hukum yang lemah. Namun untuk meningkatkan marwah penegakan hukum di Indonesia salah satu cara yang harus didorong adalah meningkatkan kualitas ilmu pengatahuan dan mengedepankan nilai-nilai moral dalam proses penyelesaian tindak pidana. Sebagaimana hukum akan dapat ditegakkan apabila penegak hukum memiliki nilai-nilai moral yang tinggi dan menghindari praktik-praktif yang melemahkan kekuatan hukum.

\section{KESIMPULAN}

Kedudukan subsistem Sistem Peradilan Pidana tidak bersifat mandiri atau merdeka karena kedudukannya berada dibawah lembaga eksekutif maupun di lembaga yudikatif. Sehingga dalam menjalankan kekuasaan dan kewenangan secara independen atau terbebas dari conflict of interest tidak dapat dijamin. Faktor ketidakmandirian sistem peradilan pidana ialah banyak peraturan yang bersifat parsial dan belum integral dalam kekuasaan peradilan, aturan yang tidak harmonis dan inkonsistensi antara satu dengan lainnya. Mewujudkan sistem peradilan pidana yang terpadu dan mandiri maka diperlukan restrukturisasi penegakan hukum pidana yang dilakukan melalui peraturan perundang-undangan yang mengatur kekuasaan kehakiman. Hal ini dapat dilakukan dengan memberikan ruang yang tegas bagi independensi kekuasaan kehakiman dari pengaruh kekuasaan eksekutif maupun kekuasaan legislatif. Sehingga lembaga sub-sistem peradilan pidana harus ditempatkan di bawah kekuasan kehakiman. Oleh karena itu, rekontruksi sistem peradilan pidana akan mampu memberikan penegakan hukum yang adil dan tidak memihak. 


\section{DAFTAR PUSTAKA}

Ackerman, Bruce, (2000), "The New Separation of Power", The Harvard Law Review, Volume 113

Afifah, T., Fuqoha, F., \& Sukendar, S. (2021). Implikasi Ideologi Pancasila pada Gerakan Sosial Islam dalam Prinsip Demokrasi Konstitusional. Ajudikasi : Jurnal Ilmu Hukum,4(2), 181-191. https://doi.org/10.30656/ajudikasi.v4i2.3003

Ali, Mahrus, (2013). Asas, Teori \& Praktek Hukum Pidana Indonesia, Yogyakarta: UII Press

Appuldnopsanji, Hari Sutra Disemadi, Nyoman Serikat Putra Jaya, (2021) Reformasi "Sistem Peradilan Pidana Indonesia Berwawasan pancasila", Kertha Wicaksana: Sarana Komunikasi Dosen dan Mahasiswa, Vol.15, No. 1

Arsheldon, Samuel, Supriardoyo Simanjuntak, Kornelius Benuf, (2020), "Strategi Antisipasi Over Kapasitas Lapas Suatu Refleksi Atas Kebijakan pencegahan Penyebaran Covid-19”, Adliya: Jurnal Hukum dan Kemanusiaan, Vol. 14, No. 1

Borman, M. Syharul, (2017), "Independensi Kekuasaan Kehakiman dari Pengaruh Kekuasaan Indonesia”, Lex Journal: Kajian Hukum \& Keadilan, Vol.1, No.1

Budi Waskito, Achmad, (2018) "Implementasi SIstem Peradilan Pidana dalam Perspektif Integrasi” Jurnal Daulat Hukum, Vol.1, No. 1

Djafar Saidi, Muhammad, (2007), Perlindungan Hukum Wajib Pajak dalam Penyelesaian Sengketa, Jakarta: Rajagrafindo Persada

D. Baer, Susan, (1998), "The Public Trust Doctrine - A Tool to Make Federal Administrative Agencies Increase Protection of Public Law and Its Resources”, Boston, Boston College Environmental Affairs Law Review Vol. 15

Handoko, Duwi, (2015), Kekuasaan Kehakiman di Indonesia, Pekanbaru: Hawa dan Ahwa.

Hendrowinoto, Nurinwa Ki S, dkk, (2010), Polri Mengisi Republik, Jakarta: PTIK

Institute For Criminal Justice Reform, (2018), "Penerapan Prinsip yang Adil dalam Sistem Peradilan Pidana"

J.P, Widodo, (2012), "Reformulasi Sistem Peradilan Pidana dalam Rangka Penanggulangan Mafia Peradilan”, Jurnal Dinamika Hukum, , Nomor 12, Vol. 1

Madril, Oce, "The President's Power and Anti-Corruption Policy: What Can Be Learned from New Order Experience”, Hasanuddin Law Review, Vol. 3, Issue 3

Magnis Suseno, Frans, (2003), Etika Politik, Prinsip-Prinsip Moral Dasar Kenegaraan Modern,Jakarta: Gramedia Pustaka Utama

Mahmud Marzuki, Peter (2015), penelitian Hukum, Edisi Revisi, Surabaya: Kencana Prenada Group 
Mardihana Sari, Novi dan I Nyoman Budiana, (2020) "Limitatif Kewenangan Jaksa Penuntut Umum dalam Tindak Pidana Korupsi” Jurnal Keritha Semaya, Vol. 8, No. 9

Nawawi Arief, Barda, (1998), "Beberapa Aspek Penegakan dan Pengembangan Hukum Pidana", Bandung: PT. Citra Aditya Bakti

--------, (2008), Masalah Penegakan Hukum Pidana dalam Penanggulangan Kejahatan, Jakarta: Kencana Prenada Media Group

--------, (2013), Kapita Selekta Hukum Pidana, Bandung: PT. Citra Aditya Bakti

Pujiyono, (2012), Rekonstruksi Sistem Peradilan Pidana Indonesia dalam Perspektif Kemandirian Kekuasaan Kehakiman, Jurnal MMH, Jilid 41 No 1.

Reksodipuro, Mardjono, (1997), Hak Asasi Manusia Dalam Sistem Peradilan Pidana, Pusat Pelayanan Keadilan dan Pengabdian Hukum, Jakarta: UI.

Rokilah, R. (2020). The Role of the Regulations in Indonesia State System. Ajudikasi : Jurnal Ilmu Hukum, 4(1), 29-38. https://doi.org/10.30656/ajudikasi.v4i1.2216

Supriyanta, (2010) "Undang-Undang Nomor 8 Tahun 1981 Tentang KUHAP sebagai Sarana Mewujudkan Sistem Peradilan Pidana Terpadu," Jurnal Wacana Hukum Vol IX

Tahir, Heri, 2010, Proses Hukum yang Adil Dalam Sistem Peradilan Pidana di Indonesia, Cetakan Pertama, Yogyakarta: LaksBang Presssindo

Velentino Kaligis, Rainaldy, (2020), “Implikasi Hukum Atas revisi Undang-Undang Nomor 30 Tahun 2002 Tentang KPK Terhadap Penyelesaian Kasus Tindak Pidana Korupsi”Lex Crime, Vol. IX, No. 1

Wahidin, Samsul, 2017, Politik Penegakan Hukum di Indonesia, Yogyakarta: Pustaka Pelajar

Waluyo, Bambang, (2016), Penegakan Hukum Di Indonesia, Jakarta: Sinar Grafika

Wicaksono, Arif, Kedudukan Komisi Pemberantasan Korupsi (KPK) dalam Sistem Ketatanegaraan Republik Indonesia, http://fh.undip.ac.id/perpus, diakses pada tanggal 25 Juni 2020

Wulansari, C. D., \& Yorisca, Y. (2020). Persoalan-Persoalan Kontemporer dalam Ilmu Hukum. Ajudikasi : Jurnal Ilmu Hukum, 4(1), 83-98. https://doi.org/10.30656/ajudikasi.v4i1.1999 
AJUDIKASI : Jurnal Ilmu Hukum, Volume 5 Nomor 1, Juni 2021. Hlm 53-70

P-ISSN 2613-9995 \& E-ISSN 2614-0179 